\title{
Physiological Performance of Wheat and Barley Seeds Treated with Bioactivator
}

\author{
Andreia da Silva Almeida ${ }^{*}$, Luciana Regina Lauxen ${ }^{1}$, \\ Francisco Amaral Villela ${ }^{1}$, Geri Eduardo Meneghello ${ }^{1}$ \\ and Maria Ângela André Tillmann ${ }^{1}$
}

${ }^{1}$ Postgraduate Program in Science and Technology of Seeds, Federal University of Pelotas, Brazil.

Research Article
Received $30^{\text {th }}$ July 2011

Accepted $7^{\text {th }}$ November 2011 Online Ready $6^{\text {th }}$ December 2011

\section{ABSTRACT}

Considering the climate and soil, as well as the results achieved by breeding, different regions show a high potential for wheat and barley production. The insecticide thiamethoxan has shown positive effects on increasing the expression of vigor and biomass formation, the elevation of photosynthetic rate and increase the formation of deeper roots. The aim of this study was to evaluate the thiamethoxan influence in the physiological performance of wheat and barley seeds. It was used seeds of two wheat and barley cultivars, and product concentrations of $0.0,150,300,450,600 \mathrm{ml}$ of thiamethoxan to $100 \mathrm{~kg}$ of seeds. To evaluate the physiological quality of seeds, it was conducted the tests of germination, first count, cold, lengths of seedlings, shoots and roots and emergence in field. The product tiamethoxan stimulates the physiological performance of wheat and barley seeds, with varying intensity according to cultivar. Doses of 300 to $400 \mathrm{ml}$ of product per $100 \mathrm{~kg}$ of seeds were more effective in promoting the expression of the physiological performance of the wheat and barley seeds.

Keywords: Triticum aestivum; Hordeum vulgare; insecticide; vigor. 


\section{INTRODUCTION}

Several regions have great potential for the production of wheat and barley. The favorable climate, soil conditions and the breeding projects justify the development of technology for these crops. Among the aspects that deserve special attention to ensure the best use of production potential of wheat and barley, there is the use of high quality seeds, particularly regarding to genetic and physiological components. However, there are still few studies aimed at evaluating the physiological potential of these species (Fanan et al., 2006).

Generally, insecticides and fungicides have been evaluated for efficiency control in pests and diseases, but some can cause still unknown effects that could modify the metabolism and plant morphology (Castro et al., 2007). The bioactivator is a complex organic substance that can alter the growth, capable of acting on the DNA transcription into the plant, gene expression, membrane proteins, metabolic enzymes and mineral nutrition (Castro and Pereira, 2008). The insecticide thiamethoxan has shown positive effects, such as increased expression of vigor, biomass, increased photosynthetic rate and formation of longer roots (Campos and Silva, 2008).

The thiamethoxan is transported through the plant cells and activates several physiological reactions, like the expression of proteins that interact with different mechanisms of defense against stress, allowing the plant to better deal with adverse conditions such as drought, low $\mathrm{pH}$, high soil salinity, free radicals, stress by high temperature, toxic effects of high levels of aluminum, injuries caused by insects, wind, hail, attack of viruses and nutrient deficiency. It has phytotonic effect, in other words, faster development of the plant expressing its best effect. In soybean we observed increase in the vigor, productivity, leaf area and root length, stand with emergence more uniform and greater uniformity in the initial development (Clavijo, 2008).

Used in the treatment of soybean seeds, the thiamethoxan accelerates germination, induces further development of the embryonic axis and minimize negative effects in situations of aluminum presence, salinity and water deficit. It accelerates germination, stimulates the activity of peroxidase, preventing oxidative stress.

Moreover, it should reduce the time for the crop field, diminishing the negative effects of competition against weeds or essential nutrients in the soil (Cataneo, 2008). These effects were also observed in cotton (Lauxen et al., 2010) and carrot (Almeida et al., 2009).

Then, considering the paucity of information concerning to the effect of thiamethoxan and the potential benefits that the treatment can provide, this study aimed to evaluate the influence of thiamethoxan product in the physiological performance of wheat and barley seeds.

\section{MATERIALS AND METHODS}

The work was conducted at the Laboratory of Seed Analysis, in the Agronomy Faculty "Eliseu Maciel" of Pelotas Federal University (Brazil). It was used seeds of two cultivars of wheat (Raízes and Abalone) and two cultivars of barley (MN 610 and MN 743), treated with a commercial product containing 35 grams of thiamethoxan active ingredient per liter of product. 
The seeds were treated with increasing doses: $0,150,300,450$ and $600 \mathrm{ml}$ of product per $100 \mathrm{~kg}$ of seeds, and the treatments called $1,2,3,4$ and 5 , respectively.

The mixture (product + distilled water) was applied, with the aid of a pipette, the bottom of a transparent plastic bag and delivered in the walls of the bag to a height of $15 \mathrm{~cm}$. The spray volume used was $0.6 \mathrm{~L}$ per $100 \mathrm{~kg}$ of seeds.

\subsection{Treatment Effects Were Evaluated Using the Following Ratings}

\subsubsection{Germination}

It was used four samples of 50 seeds from each batch distributed in transparent plastic boxes on two sheets of blotting paper, moistened with 2.5 times the paper weight, placed in an incubator set in a constant temperature of $20^{\circ} \mathrm{C}$. The counts were made in the fourth and eighth day after sowing, and the evaluations were made in accordance with the criteria established by the International Seed Testing Association (ISTA, 2004), by computing the percentage of normal seedlings for each repetition.

\subsubsection{First count}

Held jointly with the germination test, it consists in recording the percentage of normal seedlings recorded in the first count of germination test, performed on the fourth day after sowing, following the Brazilian Rules for Seed Analysis (BRAZIL, 2009).

\section{$\underline{2.1 .3 \text { Test of cold }}$}

It was used four samples of 50 seeds for each treatment, in transparent plastic boxes on two sheets of blotting paper, moistened with 2.5 times the paper weight, and kept in a refrigerator set at $10^{\circ} \mathrm{C}$ for seven days. Samples were then placed in an incubator set at $25^{\circ} \mathrm{C}$. The evaluations were conducted under the Brazilian Rules for Seed Analysis (BRAZIL, 2009). The count of normal seedlings was performed on the fourth day after the test installing and the results expressed in percentages.

\subsubsection{Total length, root and shoot}

It was used eight sub-samples of 15 seedlings. The seeds were distributed in germitest paper, moistened with distilled water at a ratio of 2.5 times the dry weight of paper, and kept in an incubator set at $25^{\circ} \mathrm{C}$. The seedlings length was measured at eight days after sowing and the results expressed in centimeters per seedling.

\subsubsection{Emergence in the greenhouse}

Four samples of 50 seeds were distributed on trays containing the commercial substrate called Plantimax®. The trays were kept in the greenhouse and the evaluations were carried out eight days after sowing, counting the seedlings length equal to, or greater than $2.0 \mathrm{~cm}$. The results were expressed as percentage of seedlings.

The experimental design was completely randomized, with four replicates per species and cultivar. Data were subjected to variance analysis and adjusted by orthogonal polynomials, using the fitted equation based on the $\mathrm{F}$ test at $5 \%$ of probability. As for the implementation 
of the statistical analysis, we used the "Statistical Analysis System for Windows - WinStat" Version 1.0 (Machado and Conceição, 2003).

\section{RESULTS AND DISCUSSION}

To evaluate the behavior of seed germination of wheat and barley cultivars, it was fitted regression equations. For the resulting curves, it seems that, from the zero dose, increases in germination values increase with the dose of thiamethoxan, for the two cultivars of wheat (Figure 1A) and barley (Figure 1B). It is possible to check that from the zero dose, germination has a quadratic trend, reaching a peak, which for wheat, dose of 300 to $350 \mathrm{ml}$ of product per $100 \mathrm{~kg}$ of seed and 200 to 250 for barley, depending on the cultivar. After reaching this point, germination decreases with increasing dose of the product.
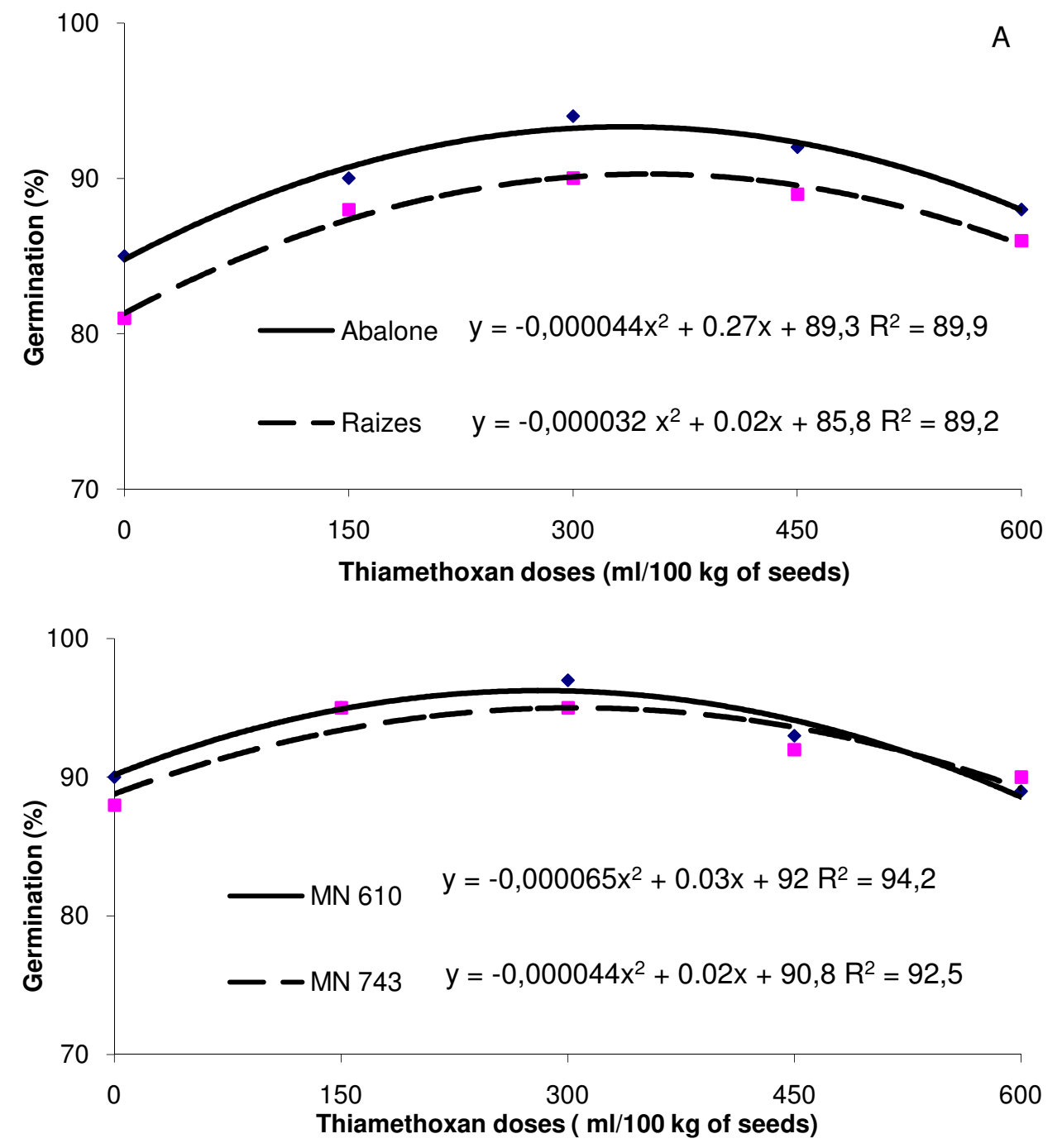

Fig. 1. Germination (\%) of seeds of two cultivars of wheat (A) and barley (B) were subjected to doses of thiamethoxan 
It is noteworthy that using adequate doses of the product, according to the cultivar, there was an increased expression of germination up to five percentage points compared to zero dose for both wheat and barley cultivars. This response was also observed by Almeida et al. (2009) on carrot seeds, Tavares et al. (2008) in soybean seeds and Clavijo (2008) in rice seeds, which revealed that thiamethoxan accelerates germination.

Analyzing the figures $2 \mathrm{~A}$ and $2 \mathrm{~B}$ we may observe a quadratic behavior in all cultivars, the test of first germination depending on the doses of thiamethoxan. It seems that from the zero dose, the curve has an increasing tendency, as well as in the germination, reaching a peak, depending on the cultivar, the dose ranges from 300 to $350 \mathrm{ml}$ of product per $100 \mathrm{~kg}$ of seeds.
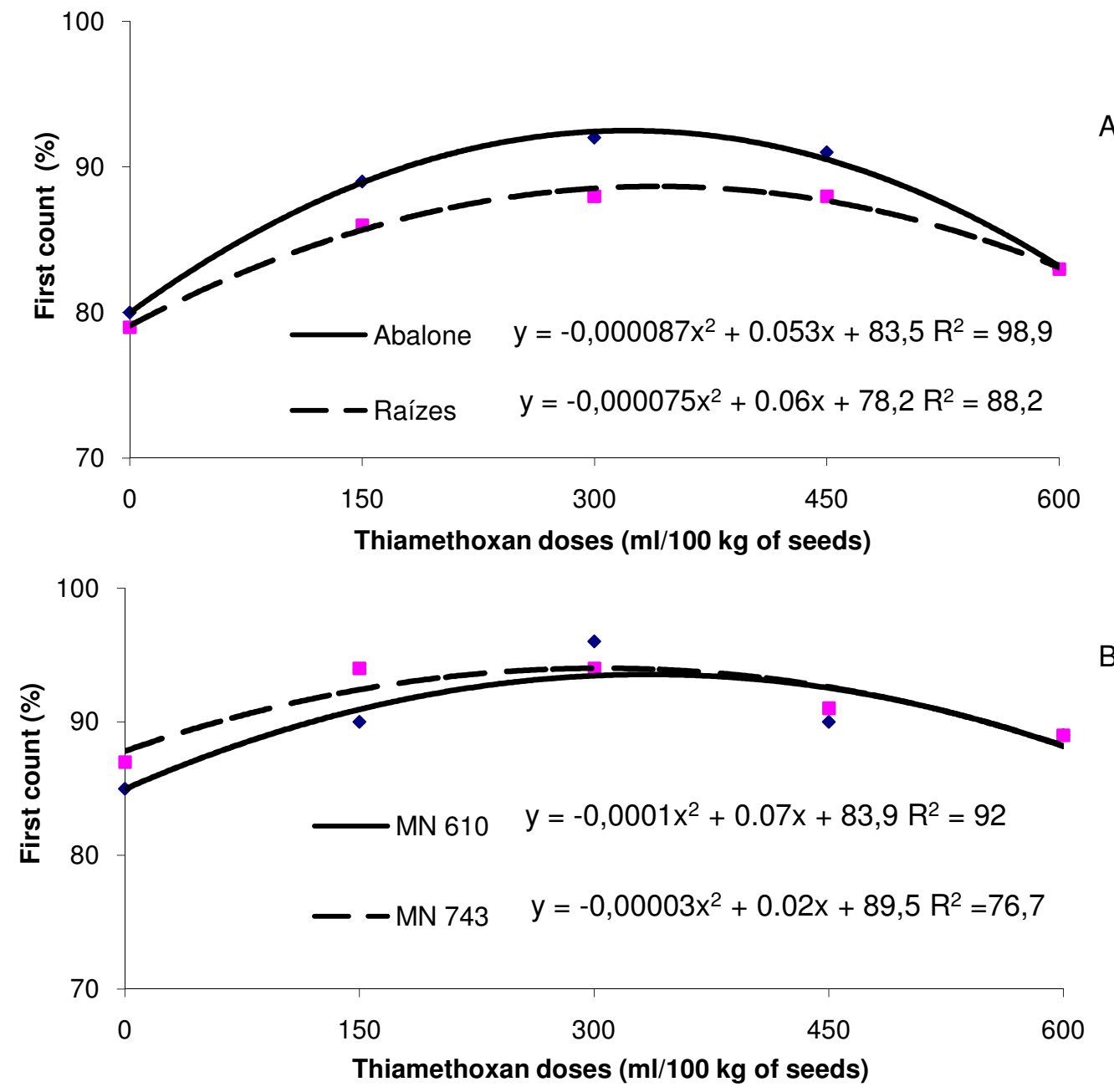

Fig. 2. First count (\%) of seed of two cultivars of wheat (A) and barley (B) were subjected to doses of thiamethoxan

From this point begins to show a decrease, with increasing dose of the product, thus, showing a quadratic response curve. For wheat cultivars, the variation of increasing doses was approximately 11 percentage points in both cultivars (Fig. 2A). For the barley cultivars, 
this increase was on average 13 percentage points (Figure 2B) for both varieties. Seeds treated with thiamethoxan has hasten germination by stimulating the enzymes activity, exhibit plant stand and more uniform emergence and better early development, as observed in soybean seeds by Castro and Pereira (2008).

The seeds showed an increase in the percentage of normal seedlings in the cold test (Figures $3 \mathrm{~A}$ and $3 \mathrm{~B}$ ), with higher dose of thiamethoxam. There is a change in behavior and trend curves are similar to the two cultivars of each species.

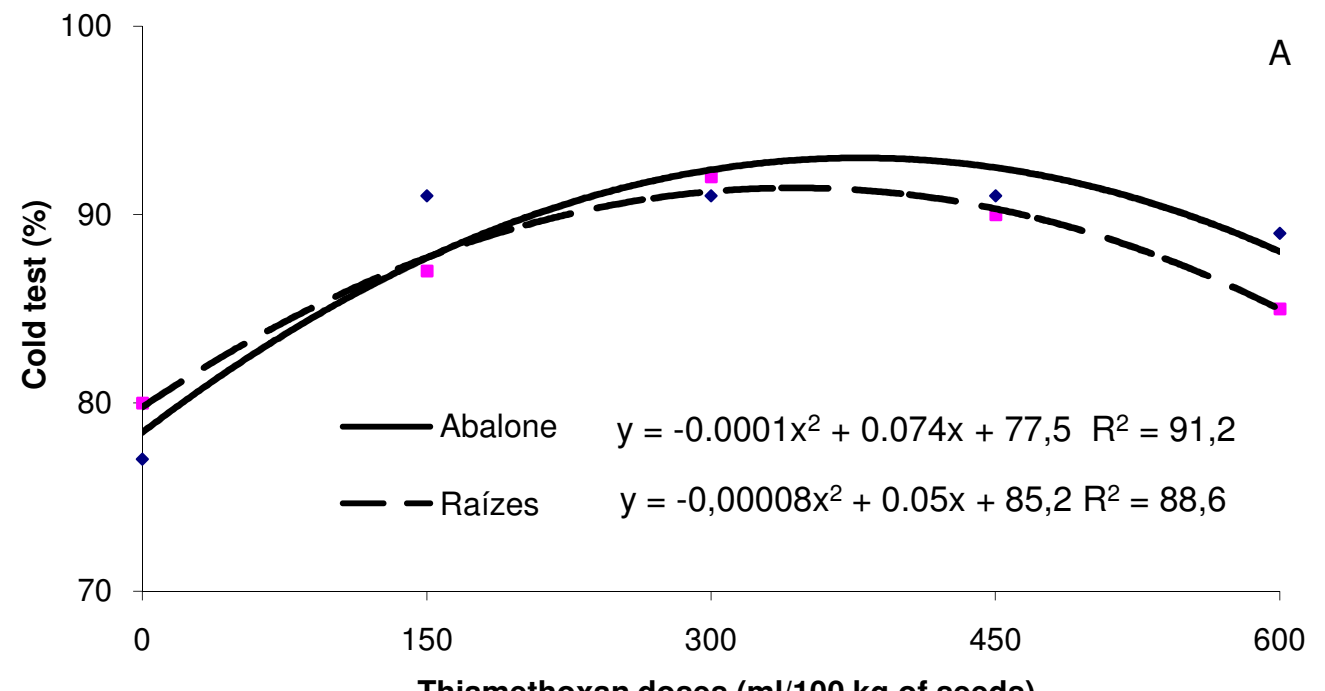

Thiamethoxan doses $(\mathrm{ml} / 100 \mathrm{~kg}$ of seeds)

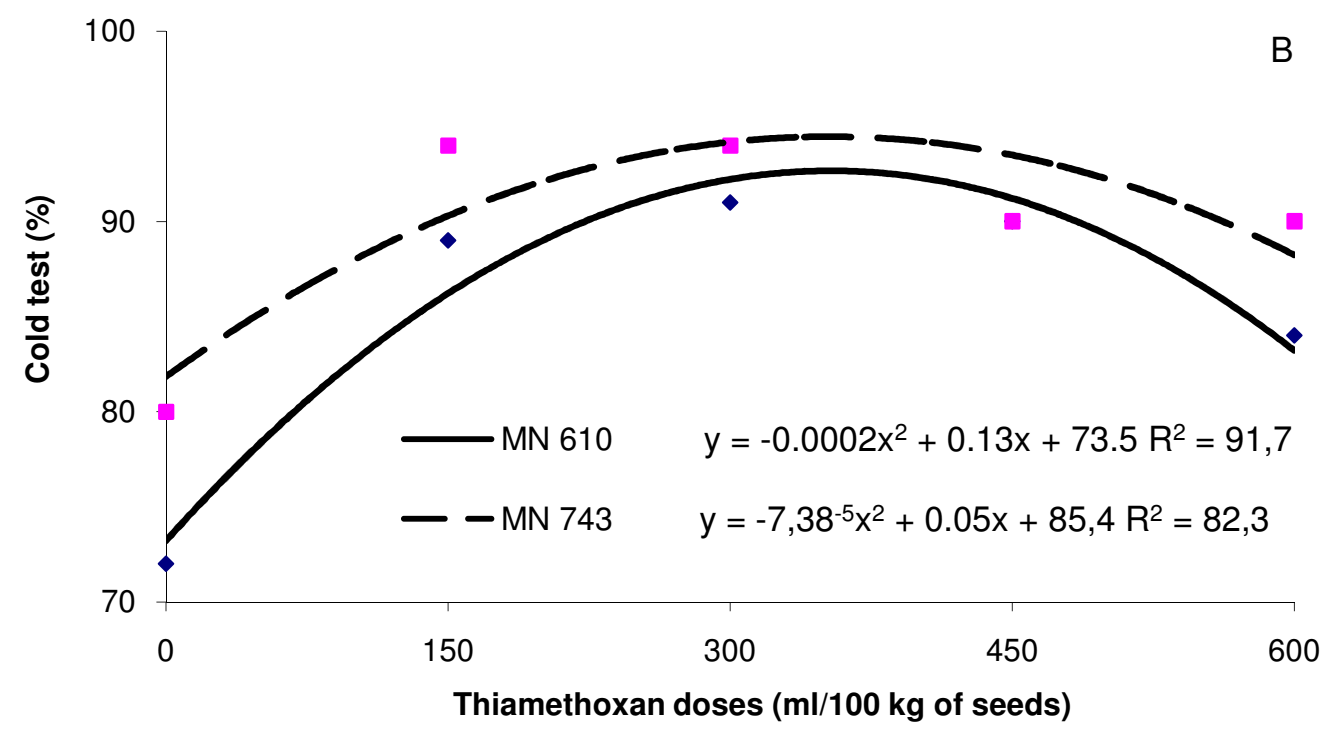

Fig. 3. Cold test (\%) of seeds of two cultivars of wheat (A) and barley (B) were subjected to doses of thiamethoxan 
As in previous assessments, it should contrast that from the zero dose, the curve has an upward trend, reaching a peak at doses ranging from 300 to $400 \mathrm{ml}$ of product per $100 \mathrm{~kg}$ of seed, depending on the cultivar. For wheat (Figure 3A), this increase was of 10 percentage points to Raízes cultivar and 16 percentage points to Abalone cultivar, when comparing the $300 \mathrm{ml} / 100 \mathrm{~kg}$ of seed and zero doses. However, in barley cultivars these increases were 17 percentage points for the cultivar MN 610 and 14 percentage points for cultivar MN 743 (Figure 3B). The vigor expression with increasing dose is probably because of the thiamethoxan movement through plant cells and as founded in soybean seeds (Tavares et al., 2008), triggering physiological responses such as activation of functional proteins related to plant defense mechanisms against stress factors, such as drought, high temperatures, toxic effects, etc., increasing the leaf and root areas and thus, contributing to the crop productivity increase.

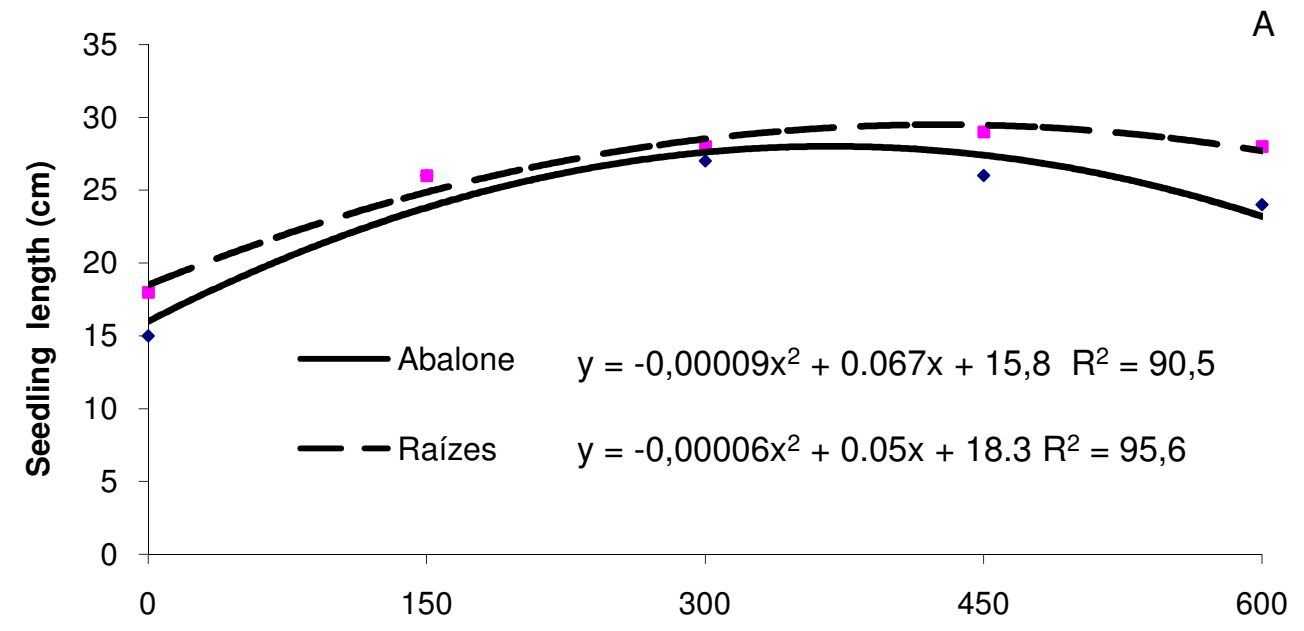

Tihiamethoxan doses ( $\mathrm{ml} / 100 \mathrm{~kg}$ of seeds)

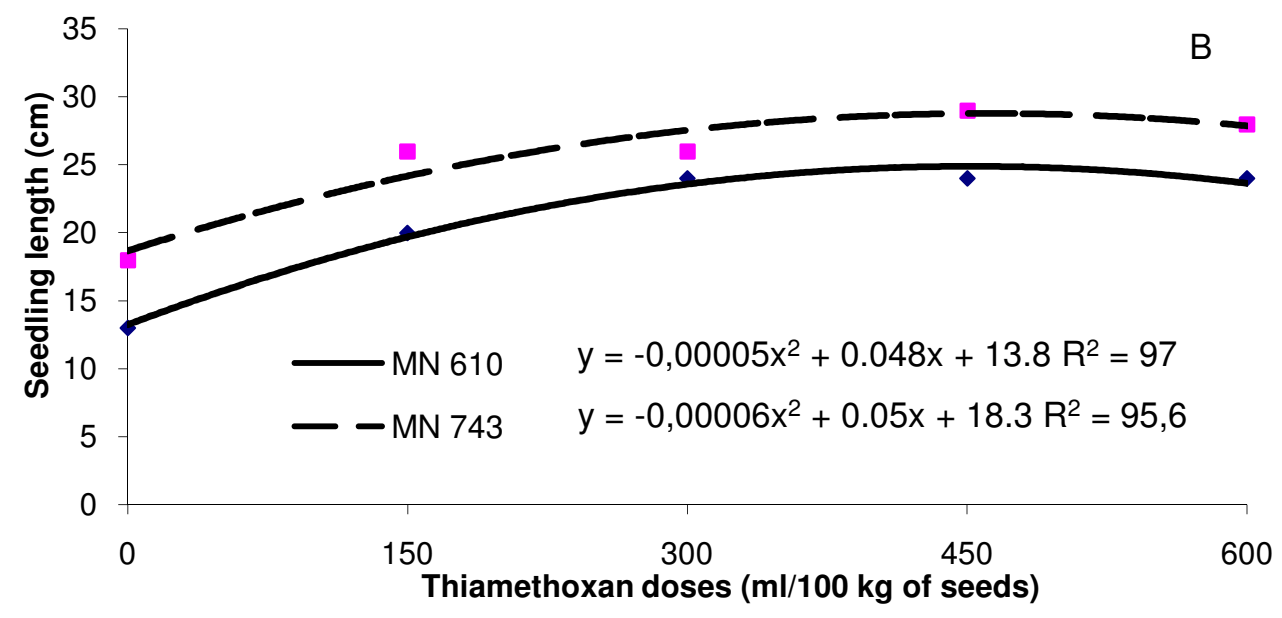

Fig. 4. Seedling length (cm) of seeds of two cultivars of wheat (FA) and barley (B) were subjected to doses of thiamethoxan

As we can see in Figure 4, the seeds of wheat (Figure 4A) and barley (Figure 4B), treated with thiamethoxan showed behaviors represented by quadratic equations, the model that 
best fit for all cultivars. The length of seedlings showed a peak for rates from 400 to $450 \mathrm{ml}$ of product per $100 \mathrm{~kg}$ of seeds, depending on variety.

For wheat (Figure 4A), the dose of $400 \mathrm{ml}$ of product, has raised an average of $12 \mathrm{~cm}$ length of seedlings when compared to seeds that have not received the product. In barley cultivars (Figure 4B), the average increase was $10 \mathrm{~cm}$ when compared to dose 0 and $400 \mathrm{ml} / 100 \mathrm{~kg}$ of seed. This difference between the zero dose and the dose that showed the greatest response, containing thiamethoxam, it may be explained by the hypothesis that thiamethoxan favors water uptake and stomatal resistance, improving the water balance of the plant, tolerating water deficit better (Castro et al., 2007). As we can observe in soybean (Tavares et al., 2008) and carrot (Almeida et al., 2009), root development increases the absorption of nutrients, increasing leaf area and the expression of plant vigor.
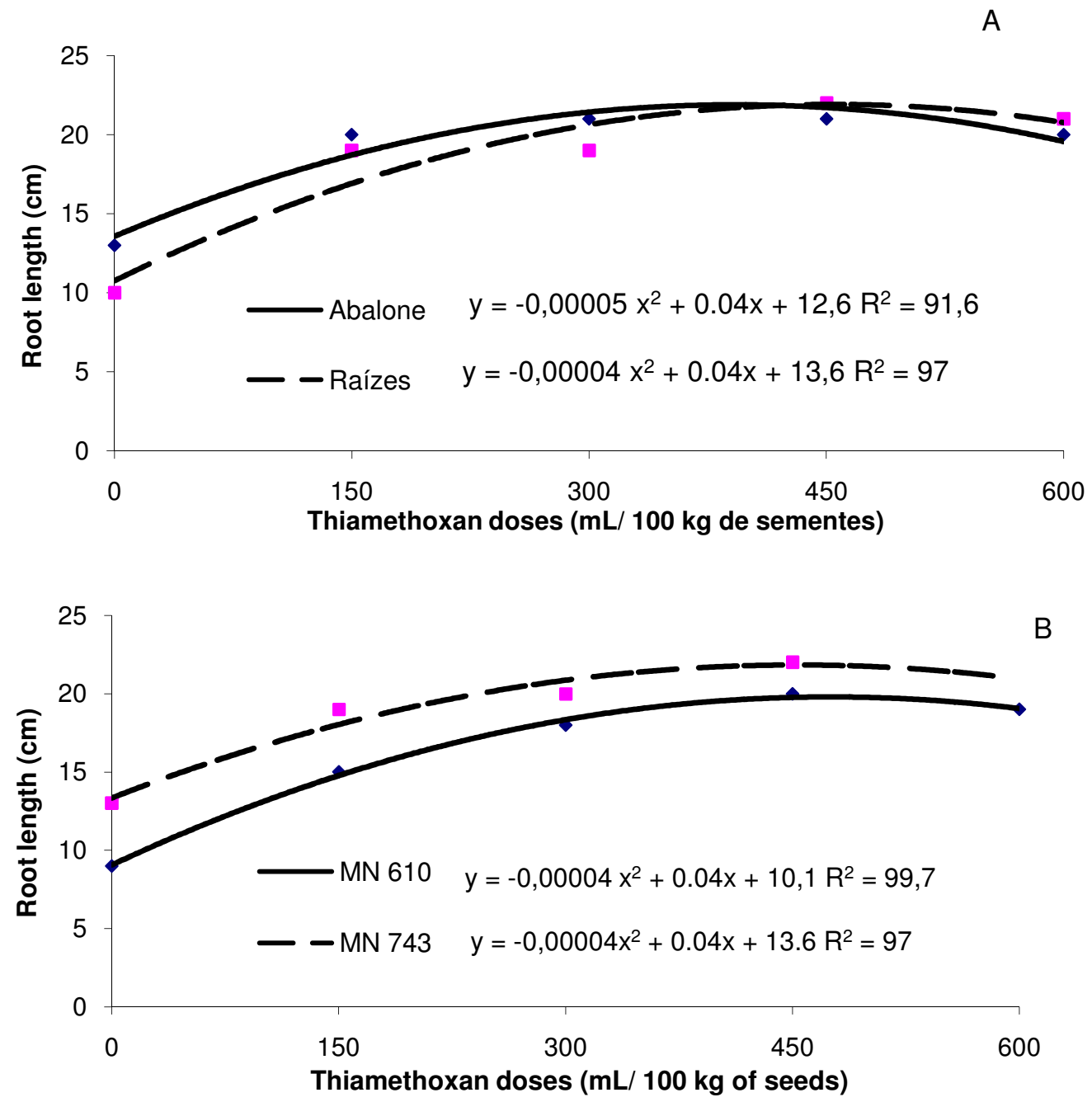

Fig. 5. Root length (cm) of seedling of two cultivars of wheat (A) and barley (B) were subjected to doses of thiamethoxan 
When observing the data presented in Figure 5, it seems that the treated seeds show seedlings with a root length increases, when increasing the dose. This effect of thiamethoxan on increasing the root length, it corroborates the rooting effect observed by Gazzoni (2008) in crops of sugarcane and potatoes, and also by Tavares et al. (2007) and Castro et al. (2008) in soybeans, for Lauxen et al. (2010) in cotton seeds, by Almeida et al. (2009) on carrot seeds.

In order to emphasize that the increases in root length with increasing doses of the product in cultivars of wheat (Figure 5A) and barley (Figure 5B) was on average $8 \mathrm{~cm}$, we compare doses of 400 to $450 \mathrm{ml}$ dose of product and zero.

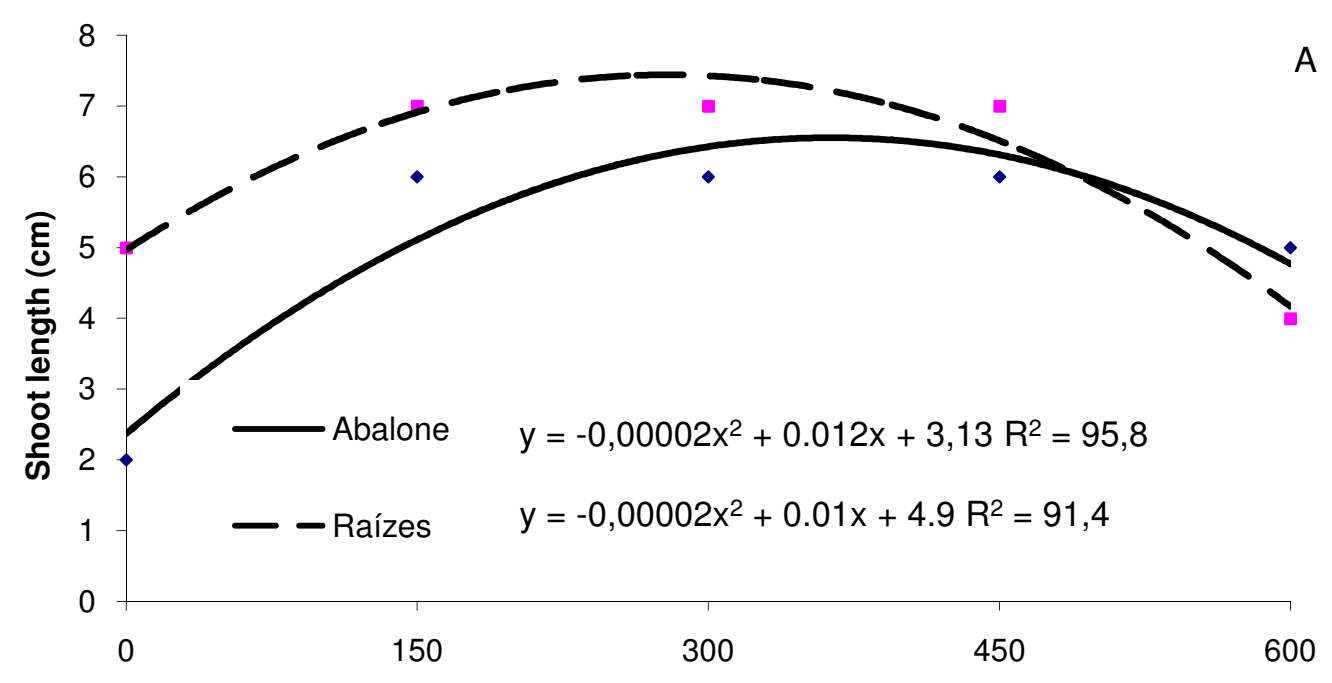

Thiamethoxan doses ( $\mathrm{ml} / 100 \mathrm{~kg}$ of seeds)

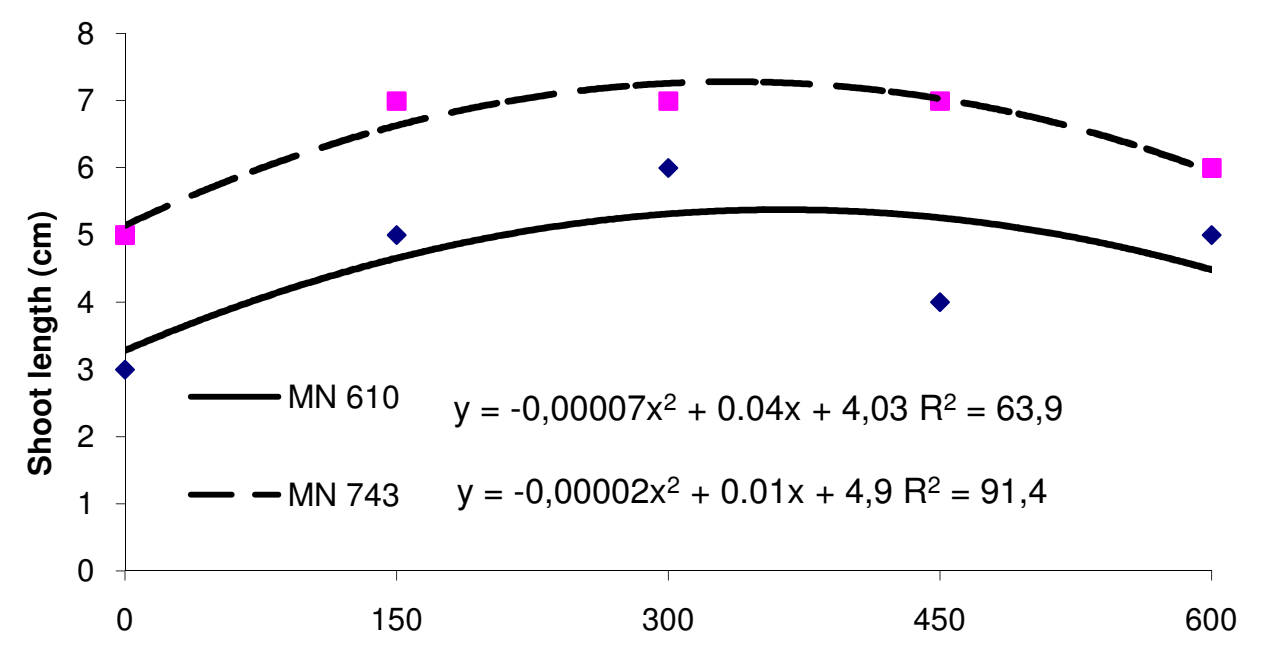

Thiamethoxan doses ( $\mathrm{ml} / 100 \mathrm{~kg}$ of seeds)

Fig. 6. Shoot length $(\mathrm{cm})$ of seedlings of two cultivars of wheat $(A)$ and barley $(B)$ were subjected to doses of thiamethoxan 
In the shoot length (Figure 6), it was found that from the zero dose, there were increases in doses of 250 to $300 \mathrm{ml}$ per $100 \mathrm{~kg}$ of seeds. Seedlings of wheat (Figure 6A) and barley cultivars (Figure 6B), whose seeds were treated with thiamethoxam, it showed an average increase of $4 \mathrm{~cm}$. It seems that maximal responses were obtained with doses between 250 and $300 \mathrm{ml}$ of product per $100 \mathrm{~kg}$ of seed, which varies according to the cultivar. The increase in shoot length with the use of thiamethoxam, depends on the dose applied, which can raise, according to Castro et al. (2007), the absorption and resistance of plant stomata to water loss by promoting metabolism and increasing resistance to stresses. Moreover, it should increase, according to Cataneo (2008), the absorption efficiency, transport and assimilation of nutrients.

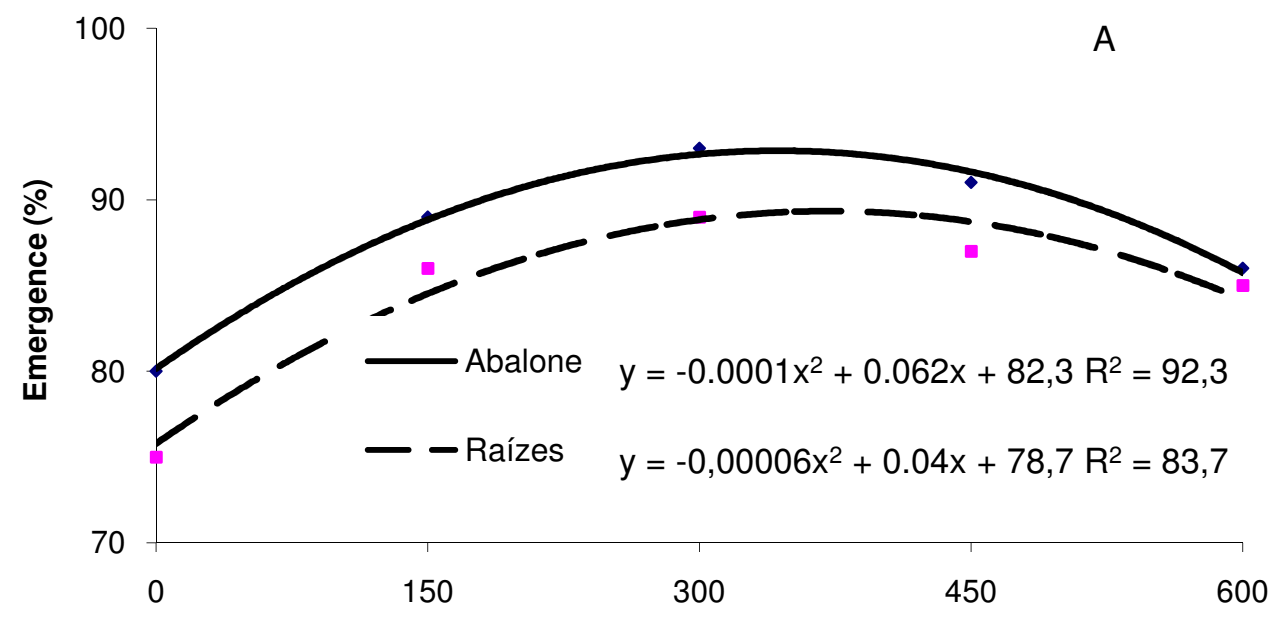

Tihiamethoxan doses ( $\mathrm{ml} / 100 \mathrm{~kg}$ of seeds)

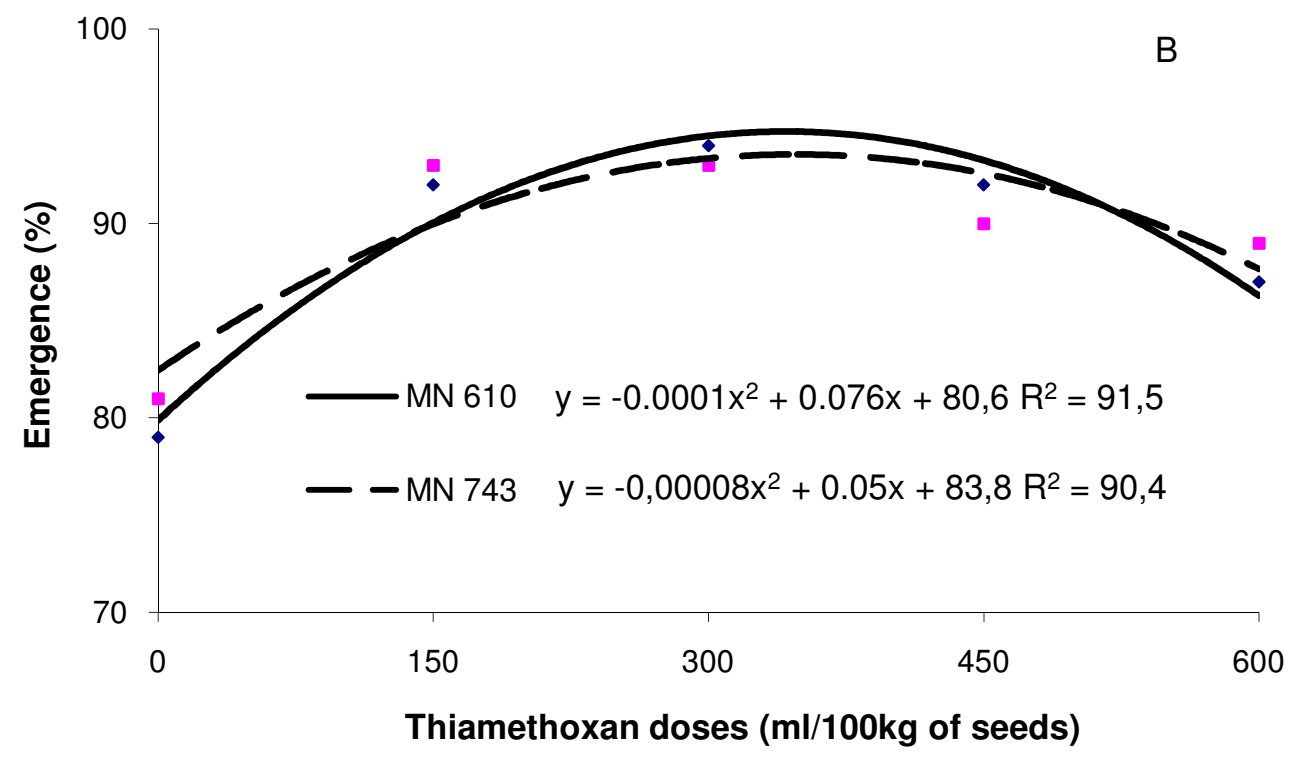

Fig. 7. Emergence (\%) of seeds of two cultivars of wheat $(A)$ and barley $(B)$ were subjected to doses of thiamethoxan 
In Figure 7, it should be observed that the emergence of seedlings in the greenhouse was stimulated when the seeds were treated with thiamethoxam, showing significant differences compared to zero dose. For wheat cultivars (Figure 7), positive differences in relation to the control treatment, varies on average by 9 percentage points. For the barley cultivars, these differences were on average 14 percentage points. According to Castro et al. (2007), soybean seeds treated with thiamethoxan have higher levels of amino acids, enzyme activity and synthesis of plant hormones, that increase the plant responses to these proteins and these events provide significant increases in production and reduce time for the establishment of the crop field, being more tolerant to stress factors.

The thiamethoxan exerts power enhancer, allowing the expression of seed germination, accelerating root growth and increasing the absorption of nutrients by the plant. These features of thiamethoxan combined with seed of high genetic and physiological quality, used to increase the productive capacity of the culture.

In a general analysis, the results show that treatment of wheat and barley seeds with thiamethoxan doses of 300 to 400 of product per $100 \mathrm{~kg}$ of seed, favors the expression of seed vigor with response intensity varying with the cultivar.

\section{CONCLUSION}

The thiamethoxan product stimulates physiologic performance of wheat and barley, with varying intensity according to the cultivar and the dose of the product.

Doses from 300 to $400 \mathrm{ml}$ of product per $100 \mathrm{~kg}$ of seed were more effective in promoting the physiological performance of the seeds of wheat and barley seeds.

\section{COMPETING INTERESTS}

Authors have declared that no competing interests exist.

\section{REFERENCES}

Almeida, A.S., Tillmann, M.A.A., Villela, F.A., Pinho, M.S. (2009). Bioactivator in physiological performance of carrot seeds. Brazilian Journal of Seeds, Brasília, 31(3), 87-95.

Calafiori, M.H., Barbieri, A.A. (2001). Effects of seed treatment with inseticide on the germination, nutrients, nodulation, yield and pest control in bean culture. Ecosystem, Espírito Santo do Pinhal., 26(1), 97-104.

Campos, B.C. de., Silva, M.T.B.(2008).Action of the thiamethoxan insecticide in the biological nitrogen fixation of soybean crop. In GAZZONI, D.L (Coord.).Thiamethoxan: a revolution in the brazilian agriculture. São Paulo: Vozes., pp. 250-264.

Castro, G.S.A., Bogiani, J.C., Silva, M.G. da, Gazola, E., Rosolem, C.A. (2008). Treatment of soybean seeds with an insecticide and a biostimulant. Brazilian Agricultural Research, Brasília, 43(10), 1311-1318.

Castro, P.R.C., Pereira, M.A. (2008). Bioactivators in agriculture. Thiamethoxam: a revolution in the Brazilian agriculture, Gazzoni, D.L. (Ed.), p. 118-126. 
Castro, P.R.C., Pitelli, A.M.C.M., Peres, L.E.P., Aramaki, P.H. (2007). Analysis of the regulatory activity of plant growth of thiamethoxan by biotests. Publicatio. UEPG (Ponta Grossa)., 13, 25-29.

Cataneo, A.C., Gazzoni, D.L. (2008). Action of thiamethoxan (Thiametoxan) on the germination of soybean seeds (Glycine max L). Enzymes involved in the mobilization of reserves and in protection against stress situation (water deficit, salinity and the presence of aluminum). Thiamethoxam: a revolution in the Brazilian Agriculture, pp. 123-192.

Fanan, S., Medina, P.F., Lima, T.C., Marcos Filho, J. (2006). Vigor evaluation of wheat seeds by accelerated aging and cold tests. Brazilian Journal of Seeds, 28(2), 152-158.

Freitas, D.B. , Bezerra, E.C., Teixeira, N.T. (2001). Aldicarb and carbofuran and nutrient content in shoots of bean crop (Phaseolus vulgaris L.) cv. Carioca 80. Ecosystems, 26(1), 68-70.

Gazzoni, D.L. (2008). Thiamethoxam: a revolution in the Brazilian agriculture: São Paulo Vozes., 342p.

International Seed Testing Association. Germination. In: ISTA. International Rules for Seed Testing. Bassersdorf: ISTA, 2004., pp. 5.1- 5.5, 5A.1- 5A.50.

Laposta, J.A. (1991). Comparison of methods for assessing physiological quality of seed cotton (Gossypium hirsutum L.). 1991. 61 f. Dissertation (Master in Agronomy - Crop Science) - Agriculture college of Lavras, Lavras.

Lauxen, L.R., Villela, F.A., Soares, R.C. (2010). Physiological performance of cotton seeds treated with thiamethoxam. Brazilian Journal of Seeds, Brasília, 32(3), 61-68.

Machado, A. de A., Conceição, A.R. (2003). WinStat: statistical analysis system for Windows. Version 2.0. Pelotas: UFPEL / NIA. Clavijo, J. (2008). Thiamethoxam: a new concept in vigor and productivity. Bogotá, Colombia,196p.

Nunes, J.C. (2006). Bioactivator of plants: an additional utility for a product originally developed as an insecticide. SEED News Magazine, Pelotas, 10(5), 30-31.

Tavares, S., Castro, P.R.C., Ribeiro, R.V., Aramaki, P.H. (2008). Evaluation of the physiological effects of thiamethoxan in the treatment of soybean seeds. Thiamethoxam: a revolution in the Brazilian agriculture. Gazzoni, D.L. (Ed.), p. 193204.

Tavares, S., Castro, P.R.C., Ribeiro, R.V., Aramaki, P.H. (2007). Evaluation of the physiological effects of thiamethoxan in the treatment of soybean seeds. Agriculture Magazine, Piracicaba, 82, 47-54.

(C) 2012 Almeida et al.; This is an Open Access article distributed under the terms of the Creative Commons Attribution License (http://creativecommons.org/licenses/by/3.0), which permits unrestricted use, distribution, and reproduction in any medium, provided the original work is properly cited. 